\title{
メンタルヘルス不調及び脳・心疾患の業務関連性の判断に係る 米国の法令等調査
}

\author{
末滿達憲 ${ }^{1}$, 奥藤達哉 ${ }^{2}$, 宮崎彰吾 ${ }^{3}$, 堀江正知 ${ }^{4}$ \\ ${ }^{1}$ 三井タワークリニック, ${ }^{2}$ 産業医科大学産業生態科学研究所健康開発科学, ${ }^{3}$ 明治大学法科大学院, \\ ${ }^{4}$ 産業医科大学産業生態科学研究所産業保健管理学
}

抄録：メンタルヘルス不調及び脳・心疾患の業務関連性 の判断に係る米国の法令等調査 : 末滿達憲ほか. 三井タ ワークリニック一近年，本邦に扔いては，精神障害また は脳血管疾患や虚血性心疾患（以下，「脑・心疾患」）と の因果関係があると解釈する範囲が拡大してきた。しか し, 本邦以外においても, 同様の解釈であるとはいえず, 海外で事業を行う企業は，その活動する国・地域におけ る法令，判例を把握することが望まれる。そこで，その 端緒として, 米国の政府機関, 大学等のホームページに 揭載された公式文書を対象として，過重労働による健康 障害に関倸する法令等を調查した。得られた知見の概要 は以下のようである。1，米国に押いては州の権限が強 く, 雇用分野の連邦法が直接適用されていたのは, 連邦 政府や州際交易の事業等における雇用の領域関係に限ら れていた。しかし，業務に関連した傷病の記録及び報告 は，全州においてほとんどの雇用主に義務づけられてお り，それに基づく全国的統計が整備されていた。2，業 務に関連した死傷病報告の対象となる疾患の基準は, CFR (Code of Federal Regulations, 2001年改正) で 明規されていた。そその改正過程において, 精神障害の取 扱いについては各界からの意見が錯綜し，最終的に現行 の「医師等による当該疾患が業務関連性を有するとの意 見書を，被雇用者が任意に雇用者に提出した場合」にの み対象とすることとなった． 3，脳・心臟疾患について の特段の基準はなく, CFRの当該個所に「既存の疾病 を有意に悪化させた場合」も業務関連があると認定する 旨が規定されているのみであった，4，民間事業所に係 る業務関連休業傷病統計（2004）によると，精神障害は

2006 年 2 月 14 日受付；2006 年 10 月 26 日受理 連絡先：末滿達憲 = 103-0022 東京都中央区日本橋室町 2 丁 目 1 番 1 号 三井タワークリニック (e-mail : tatsuem@wine.ocn.ne.jp)
約 3,000 例（常勤労働者 10,000 人当たり 0.3 例）にのほ るが, 脳・心臟疾患は合計で 500 例以下であった. 米国 に扔いては，かなりの数の業務関連性を有する精神疾患 が報告され，州政府等により職場におけるメンタルヘル スプログラムの必要性の啓発がなされていた，米国で事 業を行う日本企業がメンタルヘルス対策をとる際は，こ れらの問題に係る人々の考え方や，法制を十分に理解し た上で，プライバシーの侵害や，障害者の差別と指弾さ れることがないよう，特に留意をはかる必要があると考 えた。業務関連性を有する脳 - 心疾患の報告は数少なか った. しかし, 最近, この問題に係る文献レビューの刊 行, 会議の開催等がみられ, 近い将来には課題となる可 能性も考えられた。

(産衛誌 2007; 49: 27-34)

キーワード: Work-relatedness, Mental health failure, Cerebrovascular disease, Cardiovascular disease, United States, Legislature

\section{目的}

近年，本邦に揖いては，労働者災害補償（以下，「労 災補償」) の認定基準を示した行政の通知, 労災補償請 求対する処分の取消しを求める行政訴訟や健康被害につ いて事業者に損害賠償を請求する民事訴訟によって，い わゆる過重労働に関連して, 精神障害（以下，「メン夕 ルヘルス不調」）または脳血管疾患や虚血性心疾患（以 下, 「脳・心疾患」) との因果関係があると解釈する疾病 の範囲が拡大されてきた ${ }^{1)}$.しかし, 諸外国においては, その解釈は異なると考えられる。したがって, 海外に事 業場や関連会社を有する企業等は，各国・地域に扔ける 雇用者の責任と負担の範囲を理解して労衝衛生対策を検 討するために，当該国・地域に扔ける法令や判例を把握 
することが求められる.

そこで，本調査は，企業活動や経済面において本邦と 最も関係が深い米国について，本邦と比較しながら，労 働基準，労働安全衛生，労災補償の領域における法令の 体系の相違を調査すること，及び，メンタルヘルス不調 や脳・心疾患の業務関連性に関係する法令及びその解釈 を調査することを目的とした。

\section{方 法}

調査は，米国の法令や判例について電子的に公開して いる連邦政府のデータベース (Employment Law Guide, Office of the Assistant Secretary for Policy, Department of Labor, http://www.dol.gov/asp/programs/guide.htm), 及びコーネル大学法学部のデータベース（Law about Employment, Cornell Law School, http://www.law. cornell.edu/topics/employment.html）等を使用して検 索した労働基準，労働安全衛生，労災補償の領域に関す る法令，判例，文書等の資料を使用した。また，これら のデータベースを使用して，メンタルヘルス不調や脳・ 心疾患に関する資料，及びそれらに関連した健康診断及 び労働時間に関する資料も検索して使用した．なお，米 国における州の権限は広範で，州の立法権を制限する連 邦憲法第 1 条 [立法］第 10 節が列挙する関税に関する 事項等を除き，立法権を有していることから，資料の検
索にあたっては，必要に応じ各州の法令等も参照した。

\section{結＼cjkstart果}

1. 労働基準, 労働安全衛生, 及び労災補償に関する米 国の法令の体系

連邦法の体系は, 本邦の法律に相当する連邦法 (United States Code, USC)，政令又は省令に相当する 連邦規則 (Code of Federal Regulations, CFR) に分か れている.USCとCFRは, 領域 (Title) ごとに条文 (Article) が第 1 条から通し番号で並び，それらの条文 は分野ごとに章 (Chapter) が設けられていた（表 1)。 たとえば，労働安全衛生に関する法令は，USC と CFR ともに Title 29 に含まれ, 法令の名称は “Occupational Safety and Health Act (29USC651 et seq.)”(以下, $\lceil$ OSHA $\rfloor$ ) “Occupational Safety and Health Standard (29CFR1910)”のように表記され，各条文の名称は “29USC655”のように表記されていた。

本邦の場合, 法律等の施行時には主管省庁が施行通知 等を出し，解釈にあたりそれらの参照が必要なことが多 いが，USCの内容には，法律が制定された背景や規則 制定までの経緯が記載されていた，CFRの内容には， 随所に解説 (note) が記載されていた。また，CFRの 制定，改正時には，Federal Register（FR）に掲載され るが，パブリックコメントを求める段階の案，パブリッ

表 1 USC, CFR の構成 [USC]

\begin{tabular}{|c|c|c|}
\hline $\begin{array}{l}\text { Title } \\
\text { 1. 総則 } \\
\text { 2. 議会 } \\
\text { 3. 大統領 } \\
\text { · } \\
\text { 5. 政府機関及び } \\
\text { 28. 裁判所及び手紴雇考 } \\
\text { 29. 労働 } \\
\text { · } \\
\text { 42. 公衆衛生·福祉 } \\
\text { ·戦争及び国防 } \\
\text { 50A. 同追補 }\end{array}$ & $\begin{array}{l}\text { Chapter } \\
\text { 1. 労働統計 } \\
\text { 8. 公平労働基準 } \\
\text { · } \\
\text { · } \\
\text { 15. 労働安全衛生 } \\
\text { · 退職者所得保障 } \\
\text { · } \\
\text { · } \\
\text { · 障害者援助技術 }\end{array}$ & 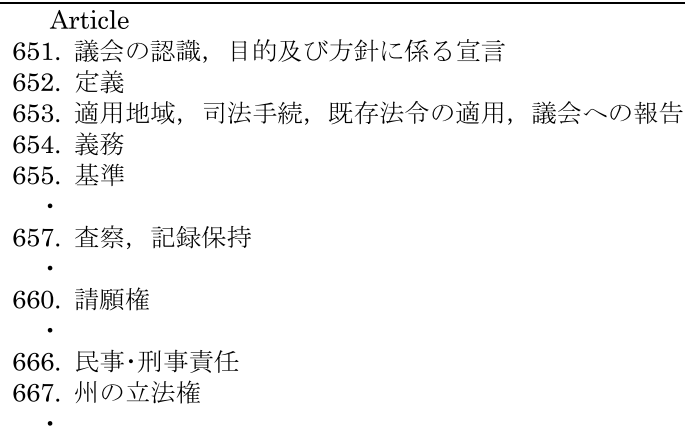 \\
\hline
\end{tabular}

[CFR]

\begin{tabular}{|c|c|c|}
\hline 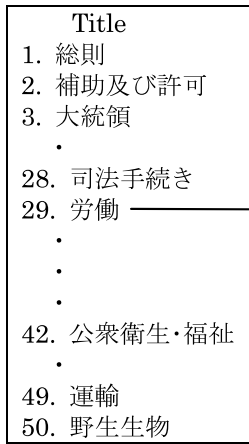 & $\begin{array}{l}\text { Chapter } \\
\text { 労働長官室 } \\
\text { · } \\
\text { I. 国家労働委員会 } \\
\text { II 労働基準部 } \\
\text { V. 賃金時間部 } \\
\text { X. } \\
\text { XIV. 雇用機会公平 } \\
\text { XV II. 安全衛生部 }\end{array}$ & $\begin{array}{l}\text { Article } \\
\text { 1902. 州基準の制定 } \\
\text { 1903. 監督, 查察, 罰則 } \\
\text { 1910. 労衝安全衛生基準 } \\
\cdot \cdot \\
\text { · } \\
\text { 1926. 建設業安全衛生規則 } \\
\text { · } \text { 安全衛生部訓練教育課 } \\
\text { 1949. } \\
\text { 1952. 州基準の強化案の承認 } \\
\text { ·. } \\
\text { 1990. 職業がんの原因と疑われる物質の同定, 分類及び規制 }\end{array}$ \\
\hline
\end{tabular}


表 2 本邦の労働基準, 労働安全衛生, 及び労災補償の領域に対応する連邦法（USC）

\begin{tabular}{|c|c|}
\hline 本邦法 & 米国連邦法 \\
\hline 労働基準法 & $\begin{array}{l}\text { Fair Labor Standard Act (FLSA) (29USC201et seq.) } \\
\text { [適用］州際通商に係る民間事業に雇用される管理職等を除く者 } \\
\text { [規定 }] \text { 最低貨金 (206条), 時間外賃金 }(207 \text { 条 })\end{array}$ \\
\hline 労働安全衛生法 & $\begin{array}{l}\text { Occupational Safety \& Health Act （OSHA）（29USC651et seq.） } \\
\text { [適用］州際通商に係る民間事業 } \\
\text { [規定］安全衛生基準 (655 条), 記録作成・行政の立入権限（657 条) }\end{array}$ \\
\hline 労働者災害補償保険法 & 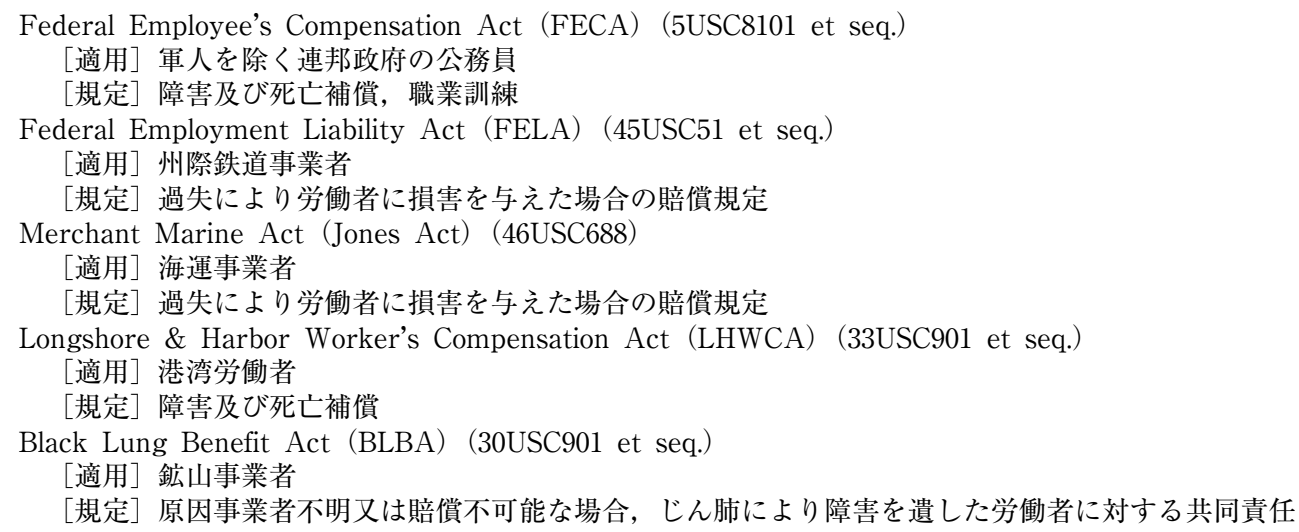 \\
\hline
\end{tabular}

クコメントに対する回答も掲載されていた.

労働基準, 安全衛生, 及び労災補償の領域における本 邦の法律に相当するUSCは，表 2 の通りであった。各 分野とも具体的な規定は原則として州法に委ねられてお り，USCの適用は，連邦公務員や各州にまたがる事業 を行う企業の従業員等に限られていた。このうち，本邦 の労働基準法に相当する法律は, “Fair Labor Standard Act (29USC201et seq.)”（以下，「FLSA」) であったが, 管理職に対する適用が除外されているなど労働基準法と 比べて労働条件の規定が包括的ではなかった. 本邦の労 働安全衛生法（以下，「安衛法」）に相当する法律は, OSHA であったが，本邦の労災補償に相当する法律は， USCでは労働の領域にまとめられておらず，行政，鉄 道, 海運, 港湾, 鉱業等の各産業分野の領域に分かれて 含まれていた．そのうち連邦政府の公務員を対象とする “Federal Employee's Compensation Act (5USC8101 et seq.)”が他の法律のモデルとなっていた。一方，製造 業やサービス業などは各州法が規定する労災補償制度に 従っていた．労災保険はほとんどの州で雇用者の強制加 入制度となっており, 州の関与の有無, 雇用者又はその グループによる保険の可否等に差異がみられた ${ }^{2)}$.

また，本邦の民法に相当する民事についての包括的な 規定はUSCの領域には認められなかった.

2. 雇用者による健康管理と労働時間管理に関する米国 の法令

本邦においては, 安衛法が事業者は労働者の健康診断 結果を記録してさまざまな健康状態に広く対応して就業
上の措置を行うために使用しなければならないことを規 定しているが，USCやCFRが規定する雇用者が被雇用 者の健康状態について把握する義務は，業務に関連した 健康状態に限定されていた。 OSHA は, 労働長官が労 働安全衛生基準を定めること（29USC655）, 雇用者及 び被雇用者がそれを遵守すべきこと（29USC654）を規 定していた．これらに基づいて規定された労働安全衛生 基準（29CFR1910）には，発がん性物質取扱業務に関 する雇用者による健康診断の実施を義務づける規定 (29CFR1910.1003（g)）等があったが, 安衛法の一般健 康診断のようにすべての労働者を対象に雇入時又は定期 に実施することは規定していなかった，逆に，米国障害 者法 (Americans with Disabilities Act, ADA (42USC12101 et seq.)) は, 被雇用者に対する医学的検査の禁止を規 定し，検査を施行することができるのは当該業務におけ る必要性が示された場合に限られることが規定されてい た。 また, ADAは, 安衛法が規定する健康保持増進活 動に相当する保健活動において既往歴を聴取するなどの 医学的検査を実施することは, 本人が任意で参加するこ とを条件に許容していた。メンタルヘルスに関する保健 活動について，カリフォルニア州労働安全衛生部による 雇用者向けパンフレット ${ }^{3)}$ は，この内容を雇用者が参 考にすることを推奨するもの, 実施しなかったことを理 由に行政措置を行うことはないことを明記したうえで， 職場のストレス対策として雇用者が被雇用者とさまざま な情報ルート（lines, channels）を維持すべきことを強 調している. 医師等による保健指導に関する記載はなか った. 
本邦においては, 労働基準法（以下，「労基法」）が労 働時間を週 40 時間に制限することや，労働者代表との 協定の締結・遵守等, 時間外労働を行わせる場合の条件, 割増貢金，監督・管理者等の除外等を規定している. FLSA も労働時間を週 40 時間に制限していたが，この 制限は通常の $150 \%$ の賃金を支払う場合には解除され， さらに，一定の条件のもとに団体交涉により割増賃金の 支払も免れることも規定されていた（29USC207（a）， (b))。また，時間外労働の規定が除外される管理・監 督者等の範囲 (29USC 213（1））は，労働長官が職務や 俸給等に基づく基準として規定することになっていた (29CFR 541.0 et seq.). その基準は，2004年 10 月 23 日 に 29 年ぶりに改正され ${ }^{4)}$ ，週給 \$155 から \$ 455 に約 3 倍に引き上げられた。しかし，それでも全米のホワイト カラーの常勤者の給与水準に照らすと下から 16.8 パー センタイルのレベルであった.

3. 労働者の精神障害または脳・心疾患の業務関連性の 判断

1）業務関連性のある死傷病の記録，報告

連邦法は，雇用者に対して，業務関連性のある死傷病 を記録し，報告する義務を規定していた（29USC657（c） (2)，673（a))。その際，業務関連性を判断する基準は 29CFR1904，1952に規定されていた（表 3)。精神疾患 の除外規定は記載されていたが，脳・心疾患の除外規定 は記載されていなかった。なお，これらの条項で規定さ れている業務関連性の判断基準は，記録と報告をするこ とを目的にしたものであり，使用者若しくは被雇用者の 過失や違反を追求すること, 又は労働者に対する補償を 認定することを意味するものではないことが， 29CFR1904.0の注釈に明記されていた.

2）精神障害の業務関連性の判断

精神障害に関係する 29CFR 1904.5 （b）（2）（）の条 項は，2001年の改正（2002年 1 月 1 日施行）により追 加されたもので, 改正案の公告 ${ }^{5)}$ 及び公布時 ${ }^{6)}$ の FR にその背景, 解説，パブリックコメント及びそれらに対 する労働安全衛生部の見解等が記載されていた．FRによ
ると, 同項は, 案の段階では, 外傷性ストレス (posttraumatic stress, 以下, PTS) に伴うものを除いて業 務関連性を認めないとされていたが，70件余りのパブ リックコメント（表 4）が寄せられ，労働安全衛生部は これらの意見を検討した結果, 表 4 の V 及びVIIの意見を 採用して, 最終的に現行の内容を規定したという経緯が 記載されていた．自殺に関係する 29CFR 1904.5 (b) (2) （一 ）の「自傷行為」の条項には, 自殺企図のような意 図的な自傷行為によるものは業務関連性を認めないと規 定されていたが，FRにその経緯の記載はなかった。

3）脳・心疾患の業務関連性の判断

脳・心疾患に関連する 29CFR1904の規定はなかった。 ただし，29CFR1904.5（b) (2)（）の「労働環境外の 事象又は曝露による結果の労働中における発現」の条項 は，「被雇用者が作業中に糖尿病による異変（incident） を呈した場合」を例示していた。これについては，FR に経緯の記載はなかった，改正時の FRによると，業務 関連性が認められない例として種々の場合を挙げるべき であるとするパブリックコメントが多く寄せられていた ことが記載されていたそそのうち，脳・心疾患に関する ものとして, 高血圧, 冠動脈疾患, 心臟発作等には業務 関連性がないことを例示すべきとのコメントが 2 件あっ たが, 労働安全衛生部はそれら疾患の労働関連性は肯定 される場合も否定される場合もあるとして，最終的にそ れらを例示しないこととしたと記載されていた。また， 29CFR1904.5（b）（4）の「既存傷病の悪化」及び同条 （b）（5）の［既存傷病とは］の条項も，例示がなかった。 FRによると，スポーツによる手首の障害後に試みに職 場復帰して悪化した事例や喘息が悪化した喫煙者の場合 には判断が困難であることから，条項の削除を求めるパ ブリックコメントが紹介されていた。しかし，脳・心疾 患に直接言及した記載は認められなかった。

4）業務関連として報告された精神障害及び脳・心疾患

29CFR1904に基づいて業務関連精神障害は，2004年 には約 3,000 件報告されていた（表5)。その内訳は，不 安, ストレス, 神経症を主とした精神障害が特に第三次 産業の事業場から多く報告されていたが, 脳・心疾患に

表 3 29CFR 1904.5が規定する業務関連性の判断基準（抄訳）

(a) 基本的要求

労働環境における事象又は曝露が当該傷病の原因となり又は発生に寄与し，若しくは既存の傷病を 有意に悪化させた場合，（b）（2）に該当する場合を除き，業務関連性があると判断する。

(b) 解釈

(1) 労働環境の定義（略）

（2）以下の一に該当する場合は業務関連ではなく，記録の対象とならない. (, ) 〜 ( ) (略)

（ ）精神疾患 精神疾患は，適切な訓練を受け，経験のある医師又は他の免許を有する医療 保健従事者（精神科医，心理学者，精神科看護師）による当該疾患が業務関連性を有するとの 意見書を，被雇用者が任意に雇用者に提出した場合を除き，業務関連性があるとは認めない。 
表 4 精神障害の業務上-外の扱いに関するパブリックコメントのまとめ（抄訳）

\begin{tabular}{|c|c|}
\hline & $\begin{array}{l}\text { 精神障害は頻度が高く，重要な問題であるので，更に検討を重ねた上で，独立の条項として取扱うべきであると } \\
\text { る意見 }\end{array}$ \\
\hline II & $\begin{array}{l}\text { PTS に限定すべきでないとする意見 } \\
\text { (1) }\end{array}$ \\
\hline III & $\begin{array}{l}\text { いかなる精神障害も記録・報告の対象とす心゙きでないとする意見 } \\
\text { (1) }\end{array}$ \\
\hline IV & $\begin{array}{l}\text { 原案に賛成 } \\
\text { ・重大事故等による本人の負傷又は同僚の死傷と精神障害との関連性の判定は容易である. }\end{array}$ \\
\hline V & 業務関連性の判定は医学に委ねるべき。 \\
\hline & $\begin{array}{l}\text { 失業，配転，懲戒に伴うものを除外すべき. （数者） } \\
\text { •ニューヨーク州労災補償法は正当な人事権の発動に原因する精神障害を対象外としている※. }\end{array}$ \\
\hline & $\begin{array}{l}\text { 被雇用者のプライバシー, 医師患者間の秘密保持擁護の必要があり, 雇用者による記録・報告は法的責任を負わ } \\
\text { れる危がある. } \\
\text { ·雇用者の記録・報告義務は被雇用者が直接又は労災補償請求を通じて雇用者に提出したものに限られるべき } \\
\text { で, それ以外は医師・患者間の秘密に立入るべきではない. }\end{array}$ \\
\hline
\end{tabular}

文献 6, pp5952-5953. I， II， III - - - (1)，(2)，(3) - - - は著者が付した.

*: 文献 7, p23.

ついては，業務関連疾患として 500 例弱の虚血性心疾患 が記録・報告されているにすぎなかった。

5）労働災害の補償

労災補償申請に対する業務関連性の判断について，連 邦公務員を対象とする FECA は，5USC8102の「被雇用 者の障害, 死亡に対する補償」において, 被雇用者が職 務遂行中に障害又は死亡をこうむった場合，連邦政府は 補償を行わねばならないとしているが，適用を除外され るものとして，(1）被雇用者の故意の安全無視行為によ るもの，(2) 被雇用者が意図的に自ら又は他人を傷害し 又は死亡させようとして生じた場合，（3）傷害を受けた 被雇用者の中毒によると考えられる場合を挙げていた.

労災補償の手続きを規定した 20CFR10.100〜 10.127 (Subpart B) は, 申請書様式及び労働者補償プログラ ム 室 (Office of Workers Compensation Programs, OWCP） が追加資料を要求する権限（20CFR10.115）に, 「傷病の事実，業務遂行中での発生，因果関係」等と記 載していたが，業務関連性の判断について補完する条項 はなかった．この規定に関係して OWCPが連邦政府の 人事・労災補償担当者及び監督者向けに作成したハンド ブック ${ }^{8)}$ は次のように記している。まず，「3-5因果関 係」の項において，29CFR1904.5（a）「業務関連性の決 定」と同様に，直接因果関係の他に，業務関連事象が既
存の傷病・状態を悪化，促進又は顕在化させた場合も対 象とすると記している．次に，「3-6 法定除外」の項に おいて，5USC8102（a）(1）～（3）を敷衍して，精神障 害のうち自殺について「事実上又は医学的証拠により， 被雇用者がその能力を十分に有していないことが示され た場合にはその傷害が補償対象となることは有り得る」 こと，すなわち，「傷害及びその結果が直接精神障害又 は身体的状態を惹起し，それらが自殺を図る衝動をもた らし又はそのような衝動を制卸する正常な思慮若しくは 判断を妨げた場合には，自殺が補償対象となることは有 り得る」ことと記している。

\section{考察}

米国の法令及びその解釈等から，メンタルヘルス不調 及び脳・心疾患に係る業務関連性の考え方を概観した。

米国においては，雇用者による業務関連性疾患の報告 が全国的に集計されており, 精神疾患としてかなりの報 告があげられているが, 脳・心疾患の報告数は僅少であ った。

連邦労働省設定の固定コホート（National Longitudinal Survey of Youth (NLSY)) 約 10,000 人に 対する超過勤務等と業務関連傷病に関する聴き取り調 査 $^{9)}$ においても，筋骨格系障害や外傷等のみが自己申 
表 5 民間事業場 ${ }^{1}$ における労働関連休業傷病 ${ }^{2}$ (業種別)（2004）(抄訳） $\bigcirc$ 精神疾患

\begin{tabular}{|c|c|c|c|c|c|c|c|c|c|c|c|}
\hline \multirow[b]{2}{*}{ 疾患 } & \multirow{2}{*}{$\begin{array}{l}\text { 業 } \\
\text { 锤 }\end{array}$} & \multirow[b]{2}{*}{ 計※ } & \multicolumn{2}{|c|}{ 製造業 ${ }^{\dagger}$} & \multicolumn{7}{|c|}{ サービス業 } \\
\hline & & & 建設業 & 工業 & $\begin{array}{l}\text { 運輸 } \\
\text { 商業等 }\end{array}$ & 情報 & 金融 & 専門職 & $\begin{array}{l}\text { 教育 } \\
\text { 医療 }\end{array}$ & $\begin{array}{l}\text { 余㗇 } \\
\text { 接客 }\end{array}$ & その他 \\
\hline \multicolumn{2}{|c|}{ 精神障害/症候群 } & $\begin{array}{l}2920 \\
(.3)^{3}\end{array}$ & $\begin{array}{l}60 \\
(.1)\end{array}$ & $\begin{array}{l}170 \\
(.1)\end{array}$ & $\begin{array}{l}800 \\
(.4)\end{array}$ & $\begin{array}{l}180 \\
(.6)\end{array}$ & $\begin{array}{l}400 \\
(.6)\end{array}$ & $\begin{array}{l}530 \\
(.4)\end{array}$ & $\begin{array}{l}380 \\
(.3)\end{array}$ & $\begin{array}{l}280 \\
(.3)\end{array}$ & $\begin{array}{l}130 \\
(.4)\end{array}$ \\
\hline \multicolumn{2}{|c|}{ 特定せず } & $\begin{array}{l}170 \\
()\end{array}$ & $-{ }^{4}$ & $\begin{array}{l}20 \\
()\end{array}$ & $\begin{array}{l}50 \\
()\end{array}$ & - & - & - & $\begin{array}{l}30 \\
()\end{array}$ & - & - \\
\hline \multicolumn{2}{|c|}{$\begin{array}{l}\text { 不安, ストレス, } \\
\text { 神経症 }\end{array}$} & $\begin{array}{l}2660 \\
(.3)\end{array}$ & - & $\begin{array}{l}150 \\
(.1)\end{array}$ & $\begin{array}{l}710 \\
(.3)\end{array}$ & $\begin{array}{l}170 \\
(.6)\end{array}$ & $\begin{array}{l}350 \\
(.5)\end{array}$ & $\begin{array}{l}520 \\
(.4)\end{array}$ & $\begin{array}{l}320 \\
(.3)\end{array}$ & $\begin{array}{l}270 \\
(.3)\end{array}$ & $\begin{array}{l}120 \\
(.4)\end{array}$ \\
\hline \multicolumn{2}{|c|}{ 特定せず } & $\begin{array}{l}1070 \\
(.1)\end{array}$ & - & $\begin{array}{l}50 \\
(\mathrm{)})\end{array}$ & $\begin{array}{l}260 \\
(.1)\end{array}$ & $\begin{array}{l}130 \\
(.4)\end{array}$ & $\begin{array}{l}150 \\
(.2)\end{array}$ & $\begin{array}{l}220 \\
(.2)\end{array}$ & $\begin{array}{l}80 \\
(.1)\end{array}$ & $\begin{array}{l}110 \\
(.1)\end{array}$ & $\begin{array}{l}- \\
(.2)\end{array}$ \\
\hline \multicolumn{2}{|c|}{$\begin{array}{l}\text { トラウマ後 } \\
\text { 不安急性 }\end{array}$} & $\begin{array}{l}280 \\
(\mathrm{)}\end{array}$ & - & - & $\begin{array}{l}90 \\
()\end{array}$ & - & - & - & $\begin{array}{l}50 \\
(\mathrm{)}\end{array}$ & $\begin{array}{l}80 \\
(.1)\end{array}$ & - \\
\hline \multicolumn{2}{|c|}{$\begin{array}{l}\text { トラウマ後 } \\
\text { 不安慢性 }\end{array}$} & $\begin{array}{l}40 \\
(\mathrm{)}\end{array}$ & - & - & - & - & - & - & - & - & - \\
\hline \multicolumn{2}{|c|}{$\begin{array}{l}\text { パニック障 } \\
\text { 害 }\end{array}$} & $\begin{array}{l}60 \\
(\mathrm{)}\end{array}$ & - & - & - & - & $\begin{array}{l}30 \\
(\mathrm{)}\end{array}$ & - & - & - & - \\
\hline \multicolumn{2}{|c|}{$\begin{array}{l}\text { ストレスに } \\
\text { 対する神経 } \\
\text { 症的反応 }\end{array}$} & $\begin{array}{l}1040 \\
(.1)\end{array}$ & - & $\begin{array}{l}80 \\
(.1)\end{array}$ & $\begin{array}{l}310 \\
(.1)\end{array}$ & $\begin{array}{l}30 \\
(.1)\end{array}$ & $\begin{array}{l}140 \\
(.2)\end{array}$ & $\begin{array}{l}210 \\
(.2)\end{array}$ & $\begin{array}{l}170 \\
(.1)\end{array}$ & $\begin{array}{l}60 \\
(.1)\end{array}$ & - \\
\hline \multicolumn{2}{|c|}{$\begin{array}{l}\text { 種々の不安, } \\
\text { ストレス, } \\
\text { 神経症 }\end{array}$} & $\begin{array}{l}120 \\
(\mathrm{)}\end{array}$ & - & - & - & - & - & - & - & - & $\begin{array}{l}50 \\
(.2)\end{array}$ \\
\hline \multicolumn{2}{|c|}{$\begin{array}{l}\text { 神経症的疾 } \\
\text { 患 }\end{array}$} & $\begin{array}{l}40 \\
()\end{array}$ & - & - & - & - & - & - & - & - & - \\
\hline \multicolumn{2}{|c|}{$\begin{array}{l}\text { 他に分類され } \\
\text { ない精神障害 } \\
\text { /症候群 }\end{array}$} & $\begin{array}{l}90 \\
()\end{array}$ & - & - & - & - & $\begin{array}{l}20 \\
(\mathrm{)})\end{array}$ & - & - & - & - \\
\hline
\end{tabular}

脳血管·心臟疾患

\begin{tabular}{|c|c|c|c|c|c|c|c|c|c|c|c|}
\hline \multirow[b]{2}{*}{ 疾患" } & \multirow{2}{*}{$\begin{array}{l}\text { 業 } \\
\text { 種 }\end{array}$} & \multirow[b]{2}{*}{ 計 } & \multicolumn{2}{|c|}{ 製造業 ${ }^{5}$} & \multicolumn{7}{|c|}{ サービス業 } \\
\hline & & & 建設業 & 工業 & $\begin{array}{l}\text { 運輸 } \\
\text { 商業等 }\end{array}$ & 情報 & 金融 & 専門職 & $\begin{array}{l}\text { 教育 } \\
\text { 医療 } \\
\end{array}$ & $\begin{array}{l}\text { 余睱 } \\
\text { 接客 } \\
\end{array}$ & その他 \\
\hline \multicolumn{2}{|c|}{$\begin{array}{l}\text { 虚血性心疾患 } \\
\text { 心臓発作を含む }\end{array}$} & $\begin{array}{l}460 \\
(.1)^{4} \\
\end{array}$ & - & $\begin{array}{l}20 \\
()\end{array}$ & $\begin{array}{l}260 \\
(.1) \\
\end{array}$ & - & - & - & - & $\begin{array}{l}280 \\
(.1) \\
\end{array}$ & - \\
\hline \multicolumn{2}{|c|}{ 心筋梗塞 } & $\begin{array}{l}420 \\
()\end{array}$ & - & $\begin{array}{l}20 \\
()\end{array}$ & $\begin{array}{l}260 \\
(.1)\end{array}$ & - & - & - & - & - & - \\
\hline
\end{tabular}

凡例 1 : 被雇用者 11 人未満の農場を除く $2: 1$ 日でも休業を要した事象 $3:($ ) 内は対常勤労働者 1 万人, (空欄) は 0.05 未満少該当なし 5 : 鉄道業データは連邦鉄道局から提供された。

※: 原典にて業種毎数の和と一致しない部分あり

†: 原典は製造業が農林漁業・鉱業, 建設業, 工業に分類されているが農林漁業・鉱業は該当ないため省略

ๆ：2003 年 データでは, この他に, 高血圧性疾患, 他の心疾患, 脳血管障害 (細分類として脳卒中) が 列挙されている.

出典 ・ http://www.bls.gov/iif/oshwc/osh/case/ostb1559.pdf - http://www.bls.gov/iif/oshwc/osh/case/ostb1582.pdf

告されており，メンタルヘルス不調，脳・心疾患を業務 関連疾患ととらえる考え方が普遍的でないことがうかが える。

本邦と米国のこのような差異をもたらす背景を法制度 の違いから探ると次の 2 点が考えられた。

1）雇用者による労働者の健康管理義務

本邦におけるような労働者に対する健康診断を実施す る義務は，有害業務に係るものに限定されており，むし ろ一般の健康診断はADAによって原則禁止されてい る.

上述の業務関連性疾病の報告についての規則改正時に
も特に精神疾患についてプライバシーの観点からの議論 がなされ，業務関連精神疾患として報告する対象が，被 雇用者が雇用者に対し任意に提出したものに限るとされ たことに留意すべきであろう。

すなわち，メンタルヘルス対策に扔いては差別，プラ イバシーの侵害との謗りを受けぬよう, 任意性, 秘匿の 確保が特に重要と考えた。

2）労働時間の制限

いわゆる過重労働の指標として, 労働時間はある程度 の客観性を有するものであり，本法における平成 17 年 11 月 2 日の安衛法改正において法制化された面接指 
導の対象として労働時間がその要件として例示されてい るところであるが，労働時間は本邦，米国いずれにおい ても週 40 時間に制限されている。 しかし，制限の緩和 要件が米国に打いて緩やかであり，特に，本邦に扔ける 監督・管理者より広い範囲がいわゆるホワイトカラー・ イグゼンプションとして割増賃金支払対象から除外され ている.すなわち, 過重労働の一つの指標たる労働時間 に対する規範性の強さに大きな差が見られる.

なお，本邦に押いてもこの制度を参考にしつつ労働時 間規制の除外が検討されている ${ }^{10)}$.

本邦において，いわゆる過重労働による健康被害対策 が司法の判断 ${ }^{11-14)}$ に促される形で進められてきたこと は否めない.

米国においても，精神疾患，心疾患の業務起因性につ いての裁判例がみられ，それによって認定基準等，立法 が対応してきた経緯もあるが，前述の通り労災補償制度 は州法に基づくので，その対応は州によって様々なよう である ${ }^{15)}$

米国に扔ける類似の判例の系統的検索は今後の課題で あるが，上に挙げたような長時間労働によって健康被害 がもたらされたとして提訴された判例は見られないよう である ${ }^{16)}$.

また，ホワイトカラー・イグゼンプション範囲の規則 改正時の $\mathrm{FR}^{4)}$ や調查研究 ${ }^{17)}$ に, 割増賃金の支払に倸 る争訟例が数多く紹介されているが，長時間労働による 健康被害に言及していると思われるものは見あたらな い.

仮に，米国において本邦にみられるような争訟例がな い，又は少ないとすれば，その原因の一つとして，両者 に扔ける「働き方」そのものの差異も挙げられよう。最 近本誌に発表された総説 ${ }^{18)}$ は, 欧米で実施された研究 が扱う overwork と本邦でいういわゆる過重労働とでは 大きな隔たりがあることを指摘している。いわゆる「過 労死」はわが国の社会経済状況の経緯や日本人固有の労 働観と関倸している ${ }^{1)}$ のであれば，その対策は医学的， 行政的介入のみならず, 社会学的調査・研究, 対策が求 められるのかもしれない.

一方，米国に打いても NIOSH が長時間労働と傷病に 係る研究のレビュー ${ }^{19)}$ を刊行する等, 脚光を浴びつつ あるものと考えられ，企業は海外の拠点において適切な 労衝衛生刘策を講ずることが望まれる。

この報告の要旨は第 78 回日本産業衛生学会総会（東 京, ’05年 4 月）にて発表した。

この報告の一部は平成 16 年度厚生労働科学研究費補 助金によった.

\section{文献}

1）寶珠山務. 過重労働とその健康障害：いわゆる過労死問題 の現状と今後の課題について．産衛誌 2003; 45: 187-193.

2) OWCP. Employment Standards Administration, U.S. Dept. of Labor. State Workers' Compensation Laws. (online), available from <http://www.dol.gov/esa/regs/ statutes/owcp/stwclaw/tables-pdf/table-1.pdf $>$, (accessed 2006-12-23).

3) Cal. Dept. of Industrial Relations, Cal / OSHA Consultation Service. Managing Stress Arising from Work, Sept. '98.

4) FR 69(79)22121-22274, Apr 23, 2004.

5) FR 61(23)4029-4067, Feb 2, 1996.

6) FR 66(13)5915-6135, Jan 19, 2001.

7) New York State Workers' Compensation Board. WorkRelated Stress Injuries in the NYS Workers' Compensation System, Sept. '97. (online), available from $<$ http://www.wcb.state.ny.us/content/main/TheBoard/st ress.pdf $>$, (accessed 2006-12-23).

8) OWCP, Employment Standards Administration, U.S. Dept. of Labor. A Handbook for Employing Agency Personnel, (Publication CA-810 (Rev. Feb. 1994)). (online), available from <http://www.dol.gov/esa/regs/compliance/owcp/feca810m.htm>, (accessed 2006-12-23) .

9) Dembe AE, Erickson JB, Delbos RG, Banks SM. The impact of overtime and long work hours on occupational injuries and illnesses: new evidence from the United States. Occup Environ Med 2005; 62: 588-597.

10）平 17.3.25 閣議決定 規制緩和・民間開放 3 か年計画（改訂） p292. (online), available from <http://www.kisei-kaikaku. go.jp/publication/2004/0325/index.html>, (accessed 2006-12-23)

11）平 8.3.28 東地判 - 平 5 （ワ） 1420 , 平 9.9 .26 東高判 - 平 8 （ネ） 1647,4089 , 平 12.3 .24 最二小判・平 10 (オ） 217 , 218 (電通事件).

12）平 10.3 .19 東地判 · 平 3 (ワ) 20 , 平 11.7 .28 東高判 · 平 10 (ネ) 1785 (システムコンサルタント事件)

13）平 12.7.17最一小判 - 平 10 (行ツ) 107 (大阪淡路交通事件).

14）平 12.7.17 最一小判 - 平 7 (行ツ） 156 （東京海上横浜支店 事件).

15) LaDOU J. Cumulative injury in worker's compensation. Occup Med 1988; 3: 611-619.

16）岩崎健二（私信）。メリーランド大学看護学部，NIOSH, 司法省主催の長時間労働に係る会議※において，NIOSH の研究者に尋ねたところ，米国に扔ける過労死に係る判例 は承知していないとのことであった.

※: Long Working Hours, Safety, And Health: Toward A National Research Agenda, April 29-30, 2004, Baltimore MD (http://nursing.umaryland.edu/ longworkhours/index.htm)

17）梶川敦子. 裁判例にみるアメリカ連邦法上の「ホワイトカ ラー・イグゼンプション」一職務要件の検討を中心に一. Vita Futura 2004; 10: 59-71.

18）藤野善久, 堀江正知, 寶珠山務, 筒井隆夫, 田中弥生. 労 
働時間と精神的負担との関連についての体系的文献レビュ 一. 産衛誌 2006; 48: 87-97.

19) NIOSH. NIOSH Publication No. 2004-143. Overtime and Extended Work Shifts: Recent Findings on Illnesses, Injuries and Health Behaviors, May 2004. (online), available from $<$ http://www.cdc.gov/niosh/docs/2004-143/>, (accessed 2006-12-24)

\title{
Study of U.S. Regulations on Determination of Work-Relatedness of Mental Health Disturbance and Cerebrovascular and Cardiac Diseases
}

\author{
Tatsunori Suemitsu ${ }^{1}$, Tatsuya OKufujI ${ }^{2}$, Shogo MiYazaki ${ }^{3}$ and Seichi Horie ${ }^{4}$ \\ ${ }^{1}$ Mitsui Tower Clinic, Nihonbashi Mitsui Tower, 1-1 Nihonbashi-Muromachi 2-Chome, Chuo, Tokyo 103-0022, Japan, \\ ${ }^{2}$ Department of Health Development, Institute of Industrial Ecological Science, University of Occupational and Environmental \\ Health, ${ }^{3}$ Meiji University Law School and ${ }^{4}$ Department of Health Management, Institute of Industrial Ecological Science, \\ University of Occupational and Environmental Health
}

\begin{abstract}
Recently, work-relatedness of mental health disturbance, cerebrovascular and ischemic heart diseases has been generously recognized in the determination of workers' compensation, in administrative or civil suits in Japan. Companies that operate overseas enterprises need to investigate legislature and court opinions in countries and regions in which they operate. In this study, we studied legislative materials concerning mental health, and cerebrovascular and cardiac diseases by reviewing official documents published on homepages provided by governmental and academic bodies in the United States. Our main findings are as follows: 1. In the United States, the state authorities have wide powers. The areas where federal employment statutes are directly applied are limited to the employment conditions of the federal government or some interstate commerce. However, almost all employers in every state are required to record and report occupational injuries and illnesses, based on which, nationwide statistics are maintained. 2. The occupational injury and illness recording criteria are clearly stated in the 2001 revision of Code of Federal Regulations (CFR). During the process of amendment, various opinions were raised concerning mental illnesses. In the final ruling, employers are required to record mental illnesses when "the employee voluntarily provides the employer with an opinion from appropriate health care providers stating that
\end{abstract}

the employee has a mental illness that is work related" (29CFR1904.5(b)(2)(ix)). 3. No specific criteria were found concerning cerebrovascular and ischemic heart disorders, except for the statement that injury or illness is considered if an event or exposure in the work environment significantly aggravates a pre-existing injury or illness (29CFR1904.5(a)). 4. According to the safety and health statistics (2004), around 3,000 cases ( 0.3 cases per 10,000 full-time workers) of mental disorders were reported in private industry workplaces. On the other hand, less than 500 cases of cerebrovascular and ischemic heart disorders were recorded. In the U.S., where significant numbers of work related mental disorders are reported, the necessity of mental health programs in workplaces is emphasized by state governments. It seems to be necessary to take care not to perform actions which might be considered as disturbance of privacy or discrimination due to disability in carrying out management measures, reflecting peoples' attitudes and legislation concerning these items. Few cases of work related cerebrovascular or ischemic heart disorders are reported in the U.S. However, recently, a reference review was published and a conference was held on this problem. Therefore it might become topical in the near future.

(San Ei Shi 2007; 49: 27-34) 